\title{
Coronaviruses - a new old menace
}

\begin{abstract}
$\mathrm{T}$ he current pandemic caused by novel coronavirus SARS-CoV-2 pandemic has been described as a global health emergency. The outbreak of this virus has raised a number of questions: what exactly is SARS-CoV-2? How transmissible the novel coronavirus is? How severely affected are patients infected with SARS-CoV-2? What are the risk factors for COVID-19? What are the differences between this novel coronavirus and other coronaviruses? To answer these questions, a comparative study of three pathogenic coronaviruses that primarily invade the human respiratory system and may cause death, namely, severe acute respiratory syndrome (SARS-CoV-1), Middle East respiratory syndrome (MERS-CoV) and severe acute respiratory syndrome coronavirus 2 (SARS-CoV-2) Middle East respiratory syndrome coronavirus (MERS-CoV). This review describes the source of origin, transmission, and pathogenicity of these viruses. Prevention of SARS-CoV-2 spreading entails home isolation of suspected cases and those with mild illnesses and strict infection control measures at hospitals that include contact and droplet precautions. The novel coronavirus spreads faster than its two predecessors - the SARS-CoV-1 and MERS-CoV - but has lower fatality rate. The global impact of this new pandemic is still uncertain, but it is a challenge to healthcare systems around the world.
\end{abstract}

\section{GENERAL CHARACTERISTIC AND TAXONOMY OF CORONAVIRUSES}

According to the latest taxonomy, coronaviruses belong to the subfamily Orthocoronavirinae in the family Coronaviridae, which also contains the subfamily Letovirinae [1]. They exhibit several common features, which include the presence of the envelope, icosahedral capsid and the genome consisting of linear positive-sense, single-stranded RNA, 26-32 kilobases $(\mathrm{kb})$ in length. Their name derives from the Latin word "corona”, which means a crown. It is associated with the characteristic appearance of virions under the electron microscope, which are surrounded by a crown of long projections. These are spike (S) peplomers, glycoproteins receiving a lot of attention from scientists as they are responsible for viral entry and membrane-fusion to host cells, thereby conditioning host specificity. It also makes them the most convenient targets for therapeutics and vaccines [2].

The taxonomy of coronaviruses has changed significantly in recent years, especially since the outbreaks of Severe Acute Respiratory Syndrome (SARS) in 2003 and Middle East Respiratory Syndrome (MERS) in 2012. Prior to that, human coronaviruses, considered a mild respiratory pathogens, did not attract much attention. In virus taxonomy release from 2002, the family Coronaviridae was divided into two genera (Coronavirus and Torovirus), which included a total of sixteen species, with three species causing infections in humans. The majority of known coronaviruses were then significant pathogens of birds (including poultry) and other mammals (including pigs) [1]. According to the latest taxonomy from 2018, the family consists of two subfamilies: Orthocoronavirinae and Letovirinae. The latter includes one species, Microhyla letovirus 1, isolated from amphibians. A much larger subfamily Orthocoronavirinae was divided into four genera: Alpha-, Beta-, Delta- and Gammacoronavirus, which currently includes thirty-eight species, most of which are bat coronaviruses [1]. In general, alpha- and beta-coronaviruses infect mammals and most of them probably originate from ancestors infecting bats, while gamma- and delta- coronaviruses are pathogenic to birds [3]. There are four lineages distinguished within the genus Betacoronavirus: A, B, C and D. SARS-CoV (Severe acute respiratory syndrome coronavirus) belongs to lineage $\mathrm{B}$ and MERS-CoV (Middle East respiratory syndrome coronavirus) to lineage C, making it the first virus within this lineage known to infect humans [4]. Recently, another human pathogen, initially known under the interim name as novel coronavirus 2019 (2019-nCoV), currently named SARS-CoV-2 (Severe acute respiratory syndrome coronavirus 2) has joined the genus Betacoronavirus.

\section{Dr n. wet. Anna Golke ${ }^{1}$,} lek. Karolina Piekarska²,

\section{dr hab. n. med. Tomasz Dzieciątkowski ${ }^{3 \boxminus}$}

${ }^{1}$ Division of Microbiology, Department of Preclinical Sciences, Faculty of Veterinary Medicine, Warsaw University of LifeSciences-SGGW ${ }^{2}$ Instituto Nacional de Enfermedades Respiratorias, Ciudad de México, Mexico ${ }^{3}$ Chair and Department of Medical Microbiology, Medical University of Warsaw

https://doi.org/10.18388/pb.2020_357

๑autor korespondujący: tdzieciatkowski@ wum.edu.pl

Key words: coronaviruses, SARS-CoV-2, COVID-19, pandemic, zoonoses

Abbreviations: CoVs - coronaviruses; FAO - Food and Agriculture Organization of the United Nations; FDA - Food and Drug Administration; ICU - intensive care unit; LAMP - loop-mediated isothermal amplification; NAT - nucleic acid tests; OIE - World Organisation for Animal Health; POC - point of care; RT-qPCR - real time reverse transcription-polymerase chain reaction; SARS - severe acute respiratory syndrome; WHO - World Health Organisation 


\section{HUMAN CORONAVIRUSES}

Until now, seven different coronaviruses have been identified in humans. Worldwide people frequently get infected with four endemic "old" human coronaviruses (HCoV229E, HCoV-NL63, HCoV-OC43, and CoV-HKU1), usually causing mild, upper respiratory tract infections, which may however develop into pneumonia [5]. HCoV-OC43 and $-229 \mathrm{E}$ were described in the 1960s and for a long time they did not raise much interest [6,7]. Further human coronaviruses have been discovered as a result of increased research in this field after the SARS outbreak in 2003. These were: HCoV-NL63 and CoV-HKU1 discovered in 2004 and 2005 , respectively $[8,9,10]$. Over the past two decades, at approximately 10-year intervals, we have also witnessed the emergence of three new epidemic species of human coronaviruses: SARS-CoV in 2002/2003, MERS-CoV in 2012 and SARS-CoV-2 in 2019 [11,12,13].

As most respiratory tract infections remain undiagnosed, it is difficult to estimate the prevalence of infections caused by individual coronaviruses. The available data in this regard usually concern patients hospitalized due to a severe course of the disease. $\mathrm{HCoV}-229 \mathrm{E}$ and $\mathrm{HCoV}-\mathrm{OC} 43$ are believed to be responsible for approximately 5 to $30 \%$ of human respiratory tract infections [14], while HCoV-NL63 for 2 to 3,6\% [15-19]. It has also been shown that in patients with acute respiratory tract infections CoV-HKU1 was detected in $0,3 \%$ of cases [5]. In addition to their presence in the respiratory system, endemic human coronaviruses can be also isolated from the gastro-intestinal tract, but they are not significant etiological agents of gastroenteritis [20].

It is believed that HCoV-NL63 and HCoV-229E originate from bat reservoirs similarly to many other coronaviruses $[21,22]$. However, HCoV-OC43 and CoV-HKU1 most likely emerged from coronaviruses infecting rodents, but in the case of HCoV-OC43 intermediary adaptation in cattle or other livestock species is suspected, which was also reflected in the taxonomy. Interestingly, $\mathrm{HCoV}-\mathrm{OC} 43$ is part of the virus species BetaCoV1 which comprises strains isolated from many different host species including primates, lagomorphs, artiodactyls, and perissodactyls and carnivores [23]. An intermediate host has also been confirmed in the case of $\mathrm{HCoV}-229 \mathrm{E}$. It is believed that this species evolved toward the human genotype in dromedary camels similarly to MERS-CoV [24].

\section{SEVERE ACUTE RESPIRATORY SYNDROME (SARS-COV-1)}

Severe acute respiratory syndrome (SARS), was the first new, severe, easily transmissible infectious disease of the 21 st century [25]. The official report of an outbreak of atypical pneumonia was received by the World Health Organization (WHO) on 11th February 2003, however first cases of this disease appeared in China (Guangdong province) in mid-November 2002. The disease was carried out of China to Hong Kong on 21st February 2003, by a doctor who had treated patients in Guangdong province [25]. Further, it spread to Viet Nam, Singapore and Canada along international travel routes. Finally, by 11th July 2003, over 8000
SARS cases had been reported from 29 countries with over 700 deaths. The main mode of SARS-CoV-1 transmission was direct person-to-person spread resulting from inhalation of respiratory droplets. The virus was detected in respiratory tract secretions, tears, feces and urine [26]. Nosocomial transmission of SARS-CoV-1 was common [27]. The incubation period for the disease varied from 2 to 10 days [28-31]. Typical clinical symptoms included fever $\left(>38^{\circ} \mathrm{C}\right)$, sometimes accompanied with chills, headache, malaise or myalgias, which were followed in 48-72 hours by dry, non-productive cough. which progressed rapidly to dyspnea often accompanied by hypoxemia. In $10-20 \%$ of cases mechanical ventilation was required. The mortality rate was high, ranging between $20-45 \%$. The highest mortality rates were recorded among elderly patients with comorbidities, as well as healthcare workers who were exposed to a high viral load [32]. SARS was rare in children and a milder course of the disease was observed. However, serological screening showed that the asymptomatic course of the disease was rare [31,33].

Basing on retrospective study revealing a high seroprevalence $(16.7 \%)$ among asymptomatic wild animal salesmen, it was hypothesized that, SARS-CoV-1 might have been transmitted from animals to humans in the wet market [34]. Moreover, a highly similar variant of SARS-CoV-1 was isolated from masked palm civets at an animal market in Shenzhen [35]. As, SARS-like coronaviruses have been also subsequently found in horseshoe bats, it was suggested that the presumed route of transmission led from bats to civets and from civets to humans. It was also suggested, that recombination between the S1 and S2 subunits of the spike gene was one of the most important mechanisms responsible for the emergence of human SARS-CoV-1 from bat and civet ancestors [36].

\section{MIDDLE EAST RESPIRATORY SYNDROME (MERS)}

MERS-CoV was incidentally discovered in Saudi Arabia in 2012. It was isolated from from the patient with acute pneumonia and subsequent renal failure with a fatal outcome [12]. Outbreaks of MERS have been mainly reported in the Middle East (Saudi Arabia, United Arab Emirates, Jordan, Qatar, Oman, Kuwait, Lebanon, Yemen, Iran), however imported cases have been also observed in Europe, Asia, Africa and North America [37].

In the course of MERS a wide spectrum of clinical manifestations has been observed, ranging from asymptomatic to acute, upper respiratory tract infection rapidly progressing into pneumonia, respiratory failure, septic shock and multiorgan failure and death. However, it is worth noting that most published clinical data relate to critically ill patients. At hospital admission, common clinical signs include: fever, chills/rigors, headache, non-productive cough, dyspnea, and myalgia, which may be accompanied by sore throat, sputum production, coryza, nausea and vomiting, diarrhea, and abdominal pain [38]. In addition to respiratory secretions, MERS-CoV has been also detected in feces, serum, and urine. Most confirmed MERS cases concerned adults, predominantly males, however, children can also become infected. The severe course of the disease, resulting in hospi- 
talization, usually concerned patients with chronic comorbidities. Based on existing data, the mortality rate is estimated at an average of 35\% [37]. In more severely ill patients, duration of MERS-CoV shedding from the respiratory tract is typically longer than in mildly ill patients, and can last even up to a month after onset [39]. No specific treatment for MERS-CoV is currently available.

The results of multiple studies have suggested that humans regularly acquire MERS-CoV from dromedary camels, a major livestock species in the Middle East. It has been also demonstrated that the majority of dromedary camels population across Middle East, Asia and Africa is seropositive for MERS-CoV. This means that, despite the possible human-to-human transmission of the virus, MERS is primarily a zoonosis [40-44].

\section{SARS-COV-2 AND CORONAVIRUS DISEASE 2019 (COVID-19)}

On 30 December 2019, a report indicating a cluster of patients with pneumonia of unknown etiology in Wuhan city, Hubei Province, China, was published on ProMEDmail [45]. On 31 December 2019, the WHO China Country Office was officially informed of this situation. A total of 44 patients with pneumonia of unknown etiology were reported to $\mathrm{WHO}$ by the national authorities in China from 31 December 2019 to 3 January 2020. Information concerning the possible association of the outbreak with exposures in one of the seafood markets in Wuhan City was forwarded to WHO on 11 and 12 January 2020. The etiological agent of the disease has been isolated and identified as a new type of coronavirus on 7 January 2020. On 12 January 2020, China shared the genetic sequence of the novel coronavirus to enable the development of diagnostic tests in other countries. On 13 January 2020 the first case of lab-confirmed novel coronavirus (2019-nCoV) was reported by Ministry of Public Health in Thailand, on 15 January 2020 first case was reported in Japan and on 20 January 2020 in Republic of Korea [46].

As of 23 January it has become clear that human-to-human transmission of this virus is possible. However, there have been very few reports of hospital outbreaks which was characteristic for MERS and SARS coronaviruses. The first case in Europe was reported in France on 27 January 2020. In end of January 2020, the novel coronavirus total case count surpassed that for SARS. On the same day WHO declared the coronavirus outbreak a Global Public Health Emergency [47].

On 11 February 2020 International Committee on Taxonomy of Viruses (ICTV) announced "severe acute respiratory syndrome coronavirus 2 (SARS-CoV-2)" as the official name of the 2019-nCoV. On the same day WHO, following the guidelines previously developed with the World Organisation for Animal Health (OIE) and the Food and Agriculture Organization of the United Nations (FAO), announced "COVID-19" as the name of this new disease. On 11 March 2020 WHO declared a pandemic [48].
Many important issues regarding SARS-CoV-2 are still unclear. In order to estimate the magnitude of the risk posed by any virus, three important parameters should be understood. Transmission rate, the number of newly infected people by a single patient, is described by the reproductive number $\left(R_{0}\right)$. On 23 January 2020, WHO estimated $R_{0}$ to be between 1,4 and 2,5. Preliminary studies had estimated $R_{0}$ to be between 1.5 and 4,13 [49], but further studies have estimated $R_{0}$ for SARS-CoV-2 between 2,24 and 4,0 [50]. Higher estimates - up to 14.8 - have been reported from single outbreaks, for example the "Diamond Princess" cruise ship [51]. For comparison, $\mathrm{R}_{0}$ for SARS-CoV-1 was 2,0 [25].

Another important parameter is the case fatality rate (CFR) which is extremely difficult to estimate during an ongoing pandemic. First of all, so far estimates rely on limited data concerning the time intervals between symptom onset and death or recovery which significantly influences the CFR. Furthermore, all CFR estimates should be carefully evaluated, as the sensitivity of surveillance of both deaths and cases in some countries is unclear. Initially (29.01.2020), the World Health Organization (WHO) estimated CFR as $2 \%$, however as of March 03rd it was 3.4\%. In China overall CFR varied according to the location and intensity of transmission. For example, in Wuhan it was 5\%, and in other areas of China 0,7\%. Generally, the overall CFR was higher at the early stages of the outbreak $(17.3 \%$ for cases with symptom onset from 1-10 January) and has decreased over time to $0.7 \%$ for patients with symptom onset after 1 st February 2020 [52]. The situation is completely different if we take into account only hospitalized patients. A study on 138 hospitalized patients with COVID-19, reported that $26 \%$ of patients required admission to the intensive care unit (ICU) and $4.3 \%$ died. It is however worth noting, that many patients were still hospitalized at the time [53]. In another study it was observed that, out of 41 patients admitted to hospital, 32\% required intensive medical care and $15 \%$ of them died [54]. It is therefore important to remember, that the differences in CFR estimates does not reflect underlying differences in disease severity between regions. They mainly depend on the sensitivity of different surveillance systems but also one the quality of the medical care offered to severely ill individuals.

Another important factor that allows to issue recommendations regarding preventive measures, is the time from exposure to the development of symptoms (the incubation period). Different studies estimated an average incubation period between 3 and 6,4 days [55]. In one study published the incubation period has been found to be as long as 24 days [56]. However, according to WHO statement, such long incubation periods could have been the result of double exposure. Therefore, currently, the incubation period of COVID-19 is estimated to be between 2 and 14 days.

SARS-CoV-2 typically causes flu-like symptoms including fever and cough (in approx. $80 \%$ of cases). In predisposed patients (elderly and individuals with chronic health conditions) - these symptoms may develop into pneumonia, with shortness of breath and chest pain. According to the Report of the WHO-China Joint Mission, the most com- 
mon clinical symptom is fever (occurring in $83 \%$ of cases), followed by cough $(82 \%)$, shortness of breath $(31 \%)$, muscle ache $(11 \%)$, confusion $(9 \%)$, headache $(8 \%)$, sore throat $(5 \%)$, rhinorrhoea $(4 \%)$, chest pain $(2 \%)$, diarrhea $(2 \%)$, nausea and vomiting $(1 \%)$. In $90 \%$ of cases more than one symptom is observed. The most important comorbidities that most often contribute to death in patients infected with SARSCoV-2 are: cardiovascular disease, diabetes, chronic respiratory disease, hypertension and cancer [52].

According to WHO recommendations, tests based on molecular biology techniques are recommended for the diagnosis of acute SARS-CoV-2 infections. Currently, realtime reverse transcriptase polymerase chain reaction (RTqPCR) is the most commonly used and preferred method for the coronavirus testing due to its sensitivity, specificity, and robustness [57]. The RT-qPCR is used for the detection of almost all the coronaviruses including SARS-CoV-2. Even so, the RT-qPCR is continuously improving to increase its specificity and sensitivity. Due to the enhanced time consumption in the sample preparation, sensitivity towards contaminations, issues in handling and analysis, an improved TaqMan based RT-qPCR assay has been introduced for the routine diagnosis of SARS-CoV-2 infections [58].

Another kind of molecular diagnostics are methods based on isothermal amplification of nucleic acids, such as the loop-mediated isothermal amplification (LAMP) technique [59]. They are tools for fast and efficient nucleic acid amplification at specified range constant temperature. An alternative is use amplicons of these isothermal reinforcements techniques enhancement a PCR to generate a variety of nucleic acid-based nanomaterials for their use in field of biomaterials, biosensors and biomedicine. A biosensor is defined as an analytical tool consisting of a transducer portion and a biological element. Besides the clinically used approaches for the diagnostics purposes in hospitals, various biosensor-based technologies are being developed, and some have already been established for the diagnosis of COVID-19 pneumonia. Therefore, biosensors are the ideal alternative tools which show rapid response, high accuracy, enhanced sensitivity with early detection possibilities $[58,59]$.

COVID-19 serological tests are mainly based on detecting specific antibodies against SARS-CoV-2 antigens. IgM are the first antibodies that appear in response to the initial exposure to an antigen, while IgG appear later and are more specific to the antigen $[58,60]$. COVID-19 serological tests for IgG and IgM have been developed by many laboratories and companies and can be useful in various ways, as they can be complementary for Nucleic Acid Tests (NAT) results or detect infected people who were negative according to NATs. Additionally, serological assays can help determine the immune status of individuals - for example in COVID-19 survivors who would donate plasma for therapeutic purposes - and estimate herd immunity level [60]. Rapid SARS-CoV-2 antigen detection kits are generally characterized by suboptimal sensitivity and specificity [58]. Nonetheless, unique and conserved domains of proteins in SARSCoV-2 could be exploited to develop sensitive testing kits. At the end of August 2020, the FDA approved the launch of the SARS-CoV-2 antigen detection test, manufactured by Abbott company, which is to be characterized by a sensitivity of $93 \%$ [61]. The dissemination of such a sensitive and quick method could significantly facilitate the rapid diagnosis of SARS-CoV-2 infections.

Regardless of whether and when the current pandemic will expire, we know that COVID-19 will not occur seasonally. Moreover, as coronaviruses are prone to mutations, the emergence of another species capable of infecting humans is unavoidable in the future perspective. Therefore, we should not stop researching coronaviruses. It should be remembered, that coronaviruses pathogenic for humans have emerged from species that are pathogenic to wild and/or livestock animals. This leads to the conclusion, that the source of the problem lies in the irresponsible violations of the natural environment. Particular attention should be paid to aspects related to the capture, trade and consumption of wild animals. Contact between livestock and wild animals should also be limited.

\section{REFERENCES}

1. https://www.avma.org/sites/default/files/2020-02/AVMA-Detailed-Coronoavirus-Taxonomy-2020-02-03.pdf (access: 10.10.2020)

2. Masters PS (2006) The molecular biology of coronaviruses. Adv Virus Res 66: 193-292. doi:10.1016/S0065-3527(06)66005-3

3. Woo PC, Lau SK, Lam CS, et al. (2012) Discovery of seven novel mammalian and avian coronaviruses in the genus delta-coronavirus supports bat coronaviruses as the gene source of alphacoronavirus and betacoronavirus and avian coronaviruses as the gene source of gammacoronavirus and deltacoronavirus. J Virol 86: 3995-4008. doi: 10.1128/JVI.06540-11

4. Cotten M, Watson SJ, Kellam P, et al. (2013) Transmission and evolution of the Middle East respiratory syndrome coronavirus in Saudi Arabia: A descriptive genomic study. Lancet 382: 1993-2002. doi: 10.1016/S0140-6736(13)61887-5

5. Lau SK, Woo PC, Yip CC, et al. (2006) Coronavirus HKU1 and other coronavirus infections in Hong Kong. J Clin Microbiol 44: 2063-2071. doi: 10.1128/JCM.02614-05

6. Hamre D, Procknow JJ (1966) A new virus isolated from the human respiratory tract. Proc Soc Exp Biol Med. 121: 190-193. doi: 10.3181/00379727-121-30734

7. McIntosh K, Dees JH, Becker WB, et al. (1967) Recovery in tracheal organ cultures of novel viruses from patients with respiratory disease. Proc Natl Acad Sci USA 57: 933-40. doi: 10.1073/pnas.57.4.933

8. Pyrc K, Berkhout B, van der Hoek L (2007) Identification of new human coronaviruses. Expert Rev Anti Infect Ther 5: 245-253. doi: 10.1586/14787210.5.2.245.

9. van der Hoek L, Pyrc K, Jebbink MF, et al (2004) Identification of a new human coronavirus. Nat Med 4: 368-373. doi: 10.1038/nm1024

10. Woo PC, Lau SK, Chu CM, et al. (2005) Characterization and complete genome sequence of a novel coronavirus, coronavirus HKU1, from patients with pneumonia. J Virol 79: 884-895. doi: 10.1128/JVI.79.2.884895.2005

11. Drosten C, Günther S, Preiser W, et al. (2003) Identification of a novel coronavirus in patients with severe acute respiratory syndrome. $\mathrm{N}$ Engl J Med 348: 1967-1976. doi: 10.1056/NEJMoa030747

12. Zaki AM, van Boheemen S, Bestebroer TM, et al. (2012) Isolation of a novel coronavirus from a man with pneumonia in Saudi Arabia. N Engl J Med 367: 1814-1820. doi: 10.1056/NEJMoa1211721.

13. Huang C, Wang Y, Li X, et al. (2020) Clinical features of patients infected with 2019 novel coronavirus in Wuhan, China. Lancet 395: 497-506. doi: 10.1016/S0140-6736(20)30183-5.

14. McIntosh K, Kapikian AZ, Turner HC, et al (1970) Seroepidemiologic studies of coronavirus infection in adults and children. Am J Epidemiol 91: 585-592. doi:10.1093/oxfordjournals.aje.a121171 
15. Arden KE, Nissen MD, Sloots TP, et al (2005) New human coronavirus, HCoV-NL63, associated with severe lower respiratory tract disease in Australia. J Med Virol 75: 455-462. doi:10.1002/jmv.20288

16. Bastien N, Anderson K, Hart L, et al (2005) Human coronavirus NL63 infection in Canada. J Infect Dis 191: 503-506. doi: 10.1086/ 426869

17. Chiu SS, Chan KH, Chu KW, et al. (2005) Human coronavirus NL63 infection and other coronavirus infections in children hospitalized with acute respiratory disease in Hong Kong, China. Clin Infect Dis 40: 1721-1729. doi: 10.1086/430301

18. Ebihara T, Endo R, Ma X, et al. (2005) Detection of human coronavirus NL63 in young children with bronchiolitis. J Med Virol 75: 463-465. doi: 10.1002/jmv.20289

19. Moës E, Vijgen L, Keyaerts E, et al. (2005) A novel pancoronavirus RT-PCR assay: frequent detection of human coronavirus NL63 in children hospitalized with respiratory tract infections in Belgium. BMC Infect Dis 5: 6. doi: 10.1186/1471-2334-5-6

20. Paloniemi M, Lappalainen S, Vesikari T (2015) Commonly circulating human coronaviruses do not have a significant role in the etiology of gastrointestinal infections in hospitalized children. J Clin Virol 62: 114117. doi: 10.1016/j.jcv.2014.10.017.

21. Pfefferle S, Oppong S, Drexler JF, et al. (2009) Distant relatives of severe acute respiratory syndrome coronavirus and close relatives of human coronavirus 229E in bats, Ghana. Emerg Infect Dis 15: 1377-1384. doi: 10.3201/eid1509.090224.

22. Tao Y, Shi M, Chommanard C, et al. (2017) Surveillance of bat coronaviruses in Kenya identifies relatives of human coronaviruses NL63 and 229E and their recombination history. J Virol 91: e01953-e01960. doi: 10.1128/JVI.01953-16

23. Corman VM, Muth D, Niemeyer D, et al. (2018) Hosts and sources of endemic human coronaviruses. Adv Virus Res 100: 163-188. doi: 10.1016/bs.aivir.2018.01.001

24. Corman VM, Eckerle I, Memish ZA, et al. (2016) Link of a ubiquitous human coronavirus to dromedary camels. Proc Natl Acad Sci USA 113: 9864-9869. doi: 10.1073/pnas.1604472113

25. Venkatesh S, Memish ZA (2004) SARS: the new challenge to international health and travel medicine. East Mediterr Health J 10: 655-662

26. Peiris JS, Yuen KY, Osterhaus AD, et al. (2003) The severe acute respiratory syndrome. N Engl J Med. 349: 2431-2441. doi:10.1056/NEJMra032498

27. Lee N, Hui D, Wu A, et al. (2003) A major outbreak of severe acute respiratory syndrome in Hong Kong. N Engl J Med 348: 1986-1994. doi: 10.1056/NEJMra032498

28. Booth CM, Matukas LM, Tomlinson GA, et al. (2003) Clinical features and short-term outcomes of 144 patients with SARS in the greater Toronto area. JAMA 289: 2801-2809, doi: 10.1001/jama.289.21.JOC30885

29. Conly JM, Johnston BL (2003) SARS: A tale of two epidemics. Can J Infect Dis 14: 147-149. doi:10.1155/2003/912170

30. Hsu LY, Lee CC, Green JA, et al. (2003) Severe acute respiratory syndrome (SARS) in Singapore: clinical features of index patient and initial contacts. Emerg Infect Dis 9: 713-717. doi:10.3201/eid0906.030264

31. Peiris JS, Chu CM, Cheng VC, et al. (2003) Clinical progression and viral load in a community outbreak of coronavirus-associated SARS pneumonia: a prospective study. Lancet 361: 1767-1772. DOI: 10.1016/ s0140-6736(03)13412-5

32. Dodek P (2004) Diabetes and other comorbidities were associated with a poor outcome in the severe acute respiratory syndrome. ACP J Club 140: 19

33. Hon KL, Leung CW, Cheng WT, et al. (2003) Clinical presentations and outcome of severe acute respiratory syndrome in children. Lancet 361: 1701-1703. doi:10.1016/s0140-6736(03)13364-8

34. Du L, Qiu JC, Wang M, et al. (2004) Analysis on the characteristics of blood serum $\mathrm{Ab}-\mathrm{IgG}$ detective result of severe acute respiratory syndrome patients in Guangzhou, China. Zhonghua Liu Xing Bing Xue Za Zhi 11: 925-928

35. Guan Y, Zheng BJ, He YQ, et al. (2003) Isolation and characterization of viruses related to the SARS coronavirus from animals in southern China. Science 302: 276-278. doi: 10.1126/science.1087139
36. Eckerle LD, Becker MM, Halpin R,A et al. (2010) Infidelity of SARS-CoV Nsp14-exonuclease mutant virus replication is revealed by complete genome sequencing. PLoS Pathog 6: e1000896. doi: 10.1371/journal.ppat.1000896

37. Ramadan N, Shaib H (2019) Middle East respiratory syndrome coronavirus (MERS-CoV): A review. Germs 9: 35-42. doi: 10.18683/ germs.2019.1155

38. Assiri A, Al-Tawfiq JA, Al-Rabeeah AA, et al .(2013) Epidemiological, demographic, and clinical characteristics of 47 cases of Middle East respiratory syndrome coronavirus disease from Saudi Arabia: a descriptive study. Lancet Infect Dis 13: 752-761. doi: 10.1016/S14733099(13)70204-4

39. Memish ZA, Al-Tawfiq JA, Makhdoom HQ, et al. (2014) Respiratory tract samples, viral load, and genome fraction yield in patients with Middle East respiratory syndrome. J Infect Dis 210: 1590-1594. doi: 10.1093/infdis/jiu292

40. Chu DK, Poon LL, Gomaa MM, et al. (2014). MERS coronaviruses in dromedary camels, Egypt. Emerg Infect Dis 20: 1049-1053. doi: 10.3201/eid2006.140299

41. Chu DK, Oladipo JO, Perera RA, et al. (2015) Middle East respiratory syndrome coronavirus (MERS-CoV) in dromedary camels in Nigeria, 2015. Euro Surveill 20 (49). doi: 10.2807/1560-7917.ES.2015.20.49.30086

42. Müller MA, Corman VM, Jores J, et al. (2014) MERS coronavirus neutralizing antibodies in camels, Eastern Africa, 1983-1997. Emerg Infect Dis 20: 2093-2095. doi: 10.3201/eid2012.141026

43. Reusken CB, Haagmans BL, Müller MA, et al. (2013) Middle East respiratory syndrome coronavirus neutralising serum antibodies in dromedary camels: a comparative serological study. Lancet Infect Dis 13: 859-866. doi: 10.1016/S1473-3099(13)70164-6

44. Saqib M, Sieberg A, Hussain MH, et al. (2017) Serologic evidence for MERS-CoV infection in dromedary camels, Punjab, Pakistan, 20122015. Emerg Infect Dis 23: 550-551. doi: 10.3201/eid2303.161285

45. Zhu N, Zhang D, Wang W, et al. (2020) A novel coronavirus from patients with pneumonia in China, 2019. N Engl J Med 82: 727-733. doi: 10.1056/NEJMoa2001017

46. Cheng ZJ, Shan J (2020) 2019 Novel coronavirus: where we are and what we know. Infection 48: 155-163. doi: 10.1007/s15010-020-01401-y

47. https:/ / www.who.int/news-room/detail/30-01-2020-statement-onthe-second-meeting-of-the-internationalhealth-regulations-(2005)emergency-committeeregarding-the-outbreak-of-novel-coronavirus-(2019-ncov) (access: 10.10.2020)

48. https://www.who.int/dg/speeches/detail/who-director-general-sopening-remarks-at-the-media-briefingon-covid-19---11-march-2020 (access: 10.10.2020)

49. Read JM, Bridgen JRE, Cummings DAT, et al. (2020) Novel coronavirus 2019-nCoV: early estimation of epidemiological parameters and epidemic predictions. medRxiv preprint https://doi. org/10.1101/2020.01.23.20018549

50. Zhao S, Lin Q, Ran J, et al. (2020) Preliminary estimation of the basic reproduction number of novel coronavirus (2019-nCoV) in China, from 2019 to 2020: A data-driven analysis in the early phase of the outbreak. Int J Infect Dis 92: 214-217. doi: 10.1016/j.ijid.2020.01.050

51. Zhang S, Diao M, Yu W, et al. (2020) Estimation of the reproductive number of novel coronavirus (COVID-19) and the probable outbreak size on the Diamond Princess cruise ship: A data-driven analysis. Int J Infect Dis 93: 201-204. doi: 10.1016/j.ijid.2020.02.033

52. https://www.who.int/docs/default-source/coronaviruse/who-china-joint-mission-on-covid-19-final-report.pdf (access: 10.10.2020)

53. Wang D, Hu B, Hu C, et al. (2020) Clinical characteristics of 138 hospitalized patients with 2019 novel coronavirus-infected pneumonia in Wuhan, China. JAMA 323: 1061-1069 doi: 10.1001/jama.2020.1585

54. Huang C, Wang Y, Li X (2020) Clinical features of patients infected with 2019 novel coronavirus in Wuhan, China. Lancet 395: 497-506. doi: 10.1016/S0140-6736(20)30183-5

55. Backer JA, Klinkenberg D, Wallinga J (2020) Incubation period of 2019 novel coronavirus (2019-nCoV) infections among travellers from $\mathrm{Wu}$ 
han, China, 20-28 January 2020. Euro Surveill 25 (5). doi: 10.2807/15607917.ES.2020.25.5.2000062

56. Guan WJ, Ni ZY, Hu Y, et al. (2020) Clinical characteristics of coronavirus disease 2019 in China. N Engl J Med 382: 1708-1720. doi: 10.1056/ NEJMoa2002032

57. Zhang S, Su X, Wang J, et al. (2020) Nucleic acid testing for coronavirus disease 2019: demand, research progression, and perspective. Crit Rev Anal Chem 19: 1-12. doi: 10.1080/10408347.2020.1805294

58. Ji T, Liu Z, Wang G, et al. (2020) Detection of COVID-19: A review of the current literature and future perspectives. Biosens Bioelectron 166: 112455. doi: 10.1016/j.bios.2020.112455
59. Augustine R, Hasan A, Das S, et al. (2020) Loop-Mediated Isothermal Amplification (LAMP): A rapid, sensitive, specific, and cost-effective point-of-care test for coronaviruses in the context of COVID-19 pandemic. Biology (Basel) 9: 182. doi: 10.3390/ biology9080182

60. Peeling RW, Wedderburn CJ, Garcia PJ, et al. (2020) Serology testing in the COVID-19 pandemic response. Lancet Infect Dis 20: e245-e249. doi:10.1016/S1473-3099(20)30517-X

61. https://www.fda.gov/media/141567/download (access: 10.10.2020)

\title{
Koronawirusy - nowe stare zagrożenie
}

\author{
Dr n. wet. Anna Golke', lek. Karolina Piekarska², dr hab. n. med. Tomasz Dzieciątkowski ${ }^{3 \llbracket}$
}

${ }^{1}$ Katedra Nauk Przedklinicznych, Wydział Medycyny Weterynaryjnej SGGW, Warszawa

${ }^{2}$ Instituto Nacional de Enfermedades Respiratorias, Ciudad de México, Mexico

${ }^{3}$ Katedra i Zakład Mikrobiologii Lekarskiej, Warszawski Uniwersytet Medyczny, Warszawa

$\bowtie$ Autor korespondencyjny: tdzieciatkowski@wum.edu.pl

Słowa kluczowe: koronawirusy, SARS-CoV-2, COVID-19, pandemia, choroby odzwierzęce

\section{STRESZCZENIE}

Obecna pandemia spowodowana przez nowego koronawirusa SARS-CoV-2 stanowi globalne wyzwanie dla zdrowia publicznego. Pojawienie się tego wirusa $w$ Chinach wywołało szereg pytań: czym właściwie jest SARS-CoV-2? Jak przenoszony jest nowy koronawirus? Jak poważnie mogą chorować pacjenci zakażeni SARS-CoV-2? Jakie są czynniki ryzyka w przebiegu COVID-19? Jakie są różnice między nowym koronawirusem a pozostałymi koronawirusami człowieka? Aby odpowiedzieć na te pytania, porównano trzy wysoce patogenne koronawirusy, które atakują głównie ludzki układ oddechowy i mogą powodować zwiększone ryzyko zgonów: koronawirusa ciężkiego ostrego zespołu oddechowego (SARS-CoV-1), koronawirusa bliskowschodniego zespołu oddechowego (MERS-CoV) oraz koronawirusa 2 ciężkiego ostrego zespołu oddechowego (SARS-CoV-2). W niniejszej pracy poglądowej opisano źródła pochodzenia, przenoszenie i chorobotwórczość tych wirusów. Zapobieganie rozprzestrzenianiu się SARS-CoV-2 w populacji obejmuje izolację w domu podejrzanych przypadków i osób z łagodnymi chorobami oraz ścisłą kontrolę zakażeń w szpitalach, dotyczącą zwłaszcza drogi kropelkowej oraz przenoszenia przez bezpośredni kontakt. Nowy koronawirus rozprzestrzenia się szybciej niż jego dwa poprzednicy - SARS-CoV-1 i MERS-CoV, ma za to niższy współczynnik śmiertelności. Wpływ nowej pandemii na funkcjonowanie ludzi jest wciąż tematem dyskusji, ale bez wątpienia COVID-19 stanowi wyzwanie dla systemów opieki zdrowotnej na całym świecie. 